\title{
Water quality assessment of fifth-order tributaries of the reservoir at the Marechal Mascarenhas de Morais Hydroelectric Power Station in the Rio Grande watershed (State of Minas Gerais, Brazil)
}

\author{
Avaliação da qualidade da água dos afluentes de quinta ordem do \\ reservatório da Usina Hidrelétrica de Marechal Mascarenhas de Morais na \\ bacia hidrográfica do médio rio Grande (Minas Gerais, Brasil)
}

Douglas de Pádua Andrade, Lucas Rezende Penido Paschoal,

Odila Rigolin de Sá and Norival França

\begin{abstract}
Laboratório de Hidrobiologia, Departamento de Ciências Biológicas, Fundaçáo de Ensino Superior de Passos - FESP, Universidade do Estado de Minas Gerais - UEMG, CEP 37900-106, Passos, MG, Brazil e-mail: douglas.p.andrade@gmail.com; lucasrezende20@gmail.com; odilarigolin@yahoo.com.br; norival.franca@fespmg.edu.br
\end{abstract}

\begin{abstract}
Aim: This study assessed the water quality from the springs and river mouths of the fifth-order tributaries which compose the reservoir of Marechal Mascarenhas de Morais HPS in the middle Rio Grande watershed, Minas Gerais, Brazil. Methods: It has been studied 14 tributaries distributed in the reservoir, two points for tributary - spring and river mouth. Eighteen limnological variables added to the Rapid Assessment Protocol and Trophic Level Index were evaluated. The benthic macroinvertebrates had been collected by the use of a granulometric sieve and a Petersen-type sampler. Results: The cluster analysis of limnological data revealed the existence of two tributary groups. Group I consisted of eutrophic tributaries degraded by human activities, while group II exhibited good water quality and well-preserved environments. Group I was divided into two subgroups, Ia tributaries were characterized by being altered by human activities, while the Ib subgroup was composed of highly impacted tributaries. By ordering the PCA, it can be observed spatial segregation of groups, where the most polluted tributaries were separated from those which are better preserved. A total of 8,987 individuals belonging to 36 families of macroinvertebrates were identified. The family Chironomidae was the most abundant. There was no significant difference in total abundance and the richness of macroinvertebrates taxa inhabiting springs, by those who inhabiting the river mouths. Conclusions: It was noticed that most of the tributaries which supply and composes the reservoir are already degraded and have low quality water. It is observed that the human presence drastically affected water quality and faunal composition of tributaries. Thus, it is necessary a complementary study of the tributaries in working with issues related to reservoirs, as these components have direct influence on the water quality and composition of these lentic environments.
\end{abstract}

Keywords: tributaries, environmental quality, benthic macroinvertebrates, anthropogenic influence, Rio Grande watershed.

Resumo: Objetivos: $\mathrm{O}$ trabalho avaliou a qualidade da água das nascentes e fozes dos afluentes de quinta ordem que abastecem o reservatório da UHE Marechal Mascarenhas de Morais na bacia do médio rio Grande, Minas Gerais. Métodos: Avaliaram-se 14 afluentes distribuídos no reservatório, sendo dois pontos por afluente - nascente e foz. Dezoito variáveis limnológicas somadas ao Protocolo de Avaliação Rápida e o Índice de Estado Trófico foram avaliados. Os macroinvertebrados bentônicos foram coletados com peneira granulométrica e pegador de fundo Petersen. Resultados: A análise de agrupamento das variáveis limnológicas revelou a existência de dois grupos. O grupo I foi composto por afluentes eutrofizados degradados por atividades humanas, enquanto que o grupo II apresentou águas de boa qualidade e ambientes preservados. Houve uma divisão do grupo I em dois subgrupos, onde Ia foi caracterizado por possuir afluentes alterados, enquanto que o subgrupo Ib foi composto por afluentes altamente impactados. Através da PCA pode-se observar segregação espacial dos grupos, onde os afluentes mais poluídos foram separados daqueles mais preservados. Um total de 8.987 indivíduos pertencentes 
a 36 famílias de macroinvertebrados foram identificados. A família Chironomidae foi a mais abundante. Não houve diferença significativa na abundância total dos macroinvertebrados bentônicos, tampouco a riqueza dos táxons de macroinvertebrados que habitavam nascentes, daqueles que habitavam fozes. Conclusóes: Verificou-se que a maior parte dos afluentes que abastecem e compóe o reservatório já se encontram degradados e possuem águas de baixa qualidade. Observa-se que a presença humana afetou drasticamente a qualidade da água e composição faunística dos afluentes. Dessa forma, faz-se necessário um estudo complementar dos afluentes ao trabalharmos com questóes ligadas a reservatórios, pois esses apresentam influência direta na qualidade da água e na composição desses ambientes lênticos.

Palavras-chave: afluentes, qualidade ambiental, macroinvertebrados bentônicos, influência antrópica, bacia hidrográfica do Rio Grande.

\section{Introduction}

Water is considered an essential resource for the possibility of life, regardless of amount or proportion. Since the beginning of human civilization, societies have been using water for a wide range of purposes and history shows that the development and success of great civilizations is often based on the abundance and correct use of water resources in a given area (USEPA, 2000).

The rapid growth of demographic density on a global scale associated with modernization in certain regions has resulted in a steady increase in power generation and water supply in urban centres. This additional demand has often required the construction of dams and reservoirs.

Most of these dams initially produced electrical energy but, in time, they were also used for a wider range of purposes. After the implementation of a dam, water quality is usually compromised due to eutrophication and the impact of human presence and activities in the surrounding areas. Obvious effects are related to the dumping of domestic effluents released without treatment, leading to changes in faunal composition (Gaufin and Tarzewell, 1952; Hodkinson and Jackson, 2005) and nutritional load of water bodies (Paschoal et al., 2012).

Tundisi (1993), Baird (1995), Straskraba and Tundisi (2000) and Ricciardi et al. (2011) list the environmental impacts caused by human actions in freshwater ecosystems, namely the reduction of canopy and riparian vegetation and topsoil erosion of fertile agricultural land due to deforestation; increased levels of contamination, toxicity and organic pollution; negative health effects on humans and other beings; biomagnification and bioaccumulation of contaminants in food chains; accelerated eutrophication due to dumping of agricultural, industrial and urban waste and untreated effluents; detriment of planktonic and benthic diversity; changes in biodiversity due to the removal of native species and the proliferation of some non native and/or invasive species.

The assessment and quantification of these environmental problems are still highly complex and costly, mainly because sources act differently in time and space. However, monitoring of water reservoirs through physical, chemical and biological analysis of water and the community structure of benthic macroinvertebrates allows the detection of possible human impact (e.g. diffuse pollution sources) that may jeopardize water usage and quality. This approach is being used in many limnological studies in Brazil (see Henry, 1999; for further details).

The evaluation, quantification and solution of environmental issues in reservoirs is nonetheless considered insufficient because these reservoirs are formed by river barriers and tributaries. It would also be necessary to verify the impacts of human presence in these hydrographical components. Consequently, the main objective of this study was to assess water quality of springs and river mouths of the fifth-order tributaries that supply the reservoir of the Marechal Mascarenhas de Morais Hydroelectric Power Station in the Middle Rio Grande watershed, Minas Gerais, Brazil. Within this context, this study was conducted based on the assumption that anthropic influence in areas surrounding the tributaries alters the environmental scenario and the quality of water that supplies the reservoir.

\section{Material and Methods}

\subsection{Study site and data sampling}

The Marechal Mascarenhas de Morais (MMM) Hydroelectric Power Station (HPS), commonly known as Peixoto, is near the city of Ibiraci (state of Minas Gerais) between the HPS's Furnas (upstream) and Luiz Carlos Barreto de Carvalho (downstream) 
in the southeast region of Minas Gerais. It is located in the middle Rio Grande watershed in a limestone zone (Romano et al., 1994). It is inserted in a region with high population density that is gaining prominence in the primary sector, where main activities are sugarcane and coffee cultivation and farming (Andrade, personal observation).

Climate of south-eastern Minas Gerais is typical of the Cerrado region with two well-defined seasons: a dry winter and a rainy summer. According to data obtained from the Agência Nacional de Águas (ANA, 2012) the dry season starts in March and April and ends between September and October. Average annual rainfall is $1300 \mathrm{~mm}, 86 \%$ of which occurs between November and March.

This study was conducted in 14 fifth-order tributaries distributed along the MMM HPS reservoir based on analysis of two points per tributary, one upstream - spring [S] and one downstream - river mouth [M] (Figure 1). Average depth of springs was $50 \mathrm{~cm}$ and average depth of river mouths was $500 \mathrm{~cm}$. Water and sediment samples were obtained quarterly between September 2009 and June 2011, in triplicate. Samples and measurements taken in situ occurred between 8:00 AM and 6:00 PM.

\subsection{Physical, chemical and biological variables of water and sediment}

Water samples were collected under the water surface with polyethylene bottles of $1000 \mathrm{~mL}$ for physical and chemical variables, except for biochemical oxygen demand and dissolved oxygen which were collected in $250 \mathrm{~mL}$ amber bottle. Packaging and preservation of the samples complied with "Standard Methods for the Examination of Water and Wastewater" (APHA, 1998).

For water quality analysis of tributaries, physical, chemical and biological variables were determined. Physical and chemical parameters analyzed in the field were $\mathrm{pH}$ - determined by readings of a digital potentiometer model PHS-3B brand PHTEK; conductivity (Cond) - digital conductivity model MB-11 brand MARS; and dissolved oxygen (DO) - method of Winkler modified with sodium azide by Golterman et al. (1978).

Recordings taken at the laboratory comprised content of organic matter (OM), alkalinity (Alk)

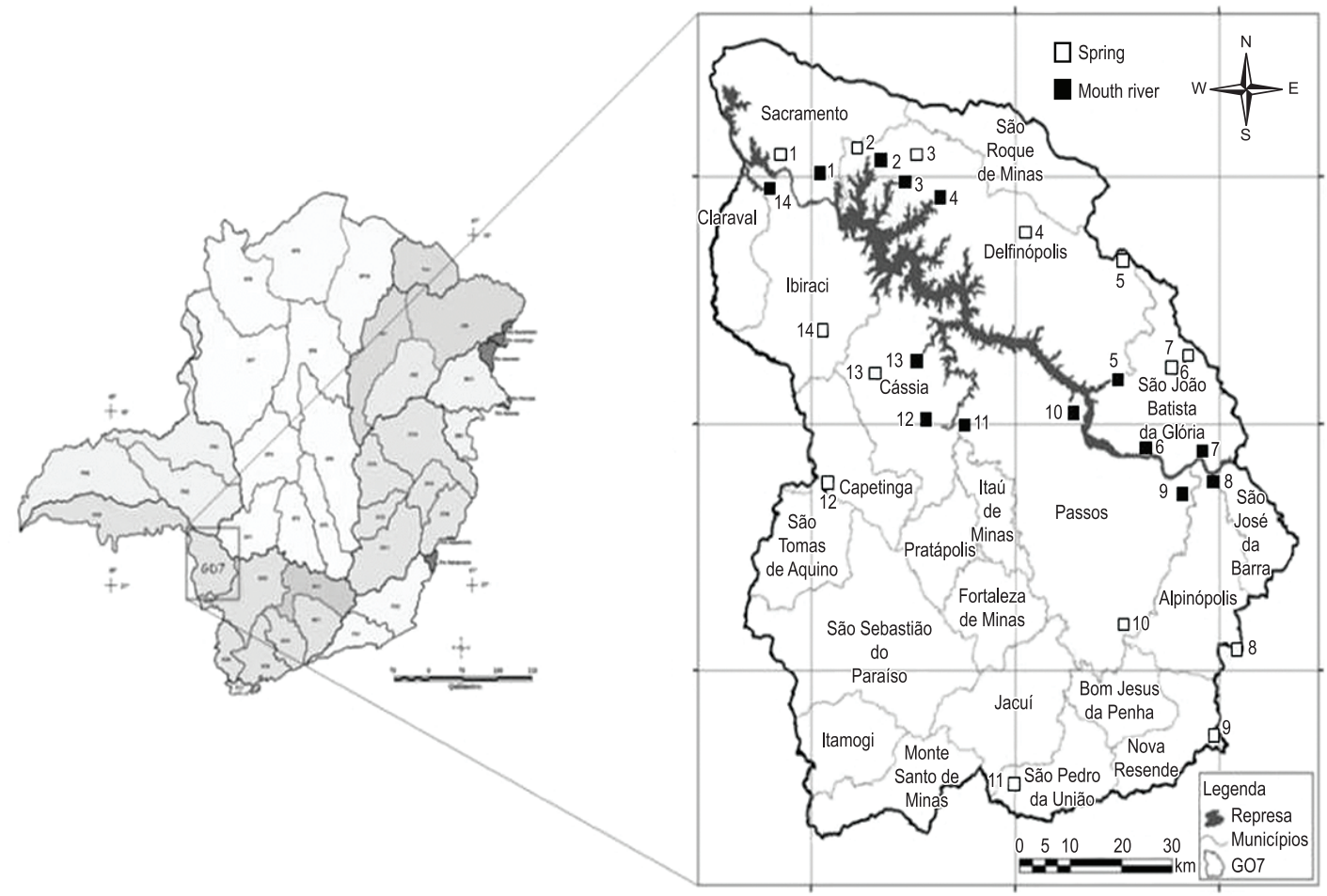

Figure 1. Location of sampling sites in the study area. 1 - RC (Ribeirão do Cavalão); 2 - RE (Ribeirão do Engano); 3 - RBJ (Ribeirão Bom Jesus); 4 - RSAN (Ribeirão Santo Antônio); 5 - RG (Ribeirão Grande); 6 - RES (Ribeirão do Esmeril); 7 - RF (Ribeirão do Fumal); 8 - RCA (Ribeirão Cancan); 9 - RCO (Ribeirão Conquista); 10 - RB (Ribeirão Bocaina); 11 - RSJ (Rio São João); 12 - RSP (Ribeirão São Pedro); 13 - CO (Córrego Onça) e 14 - RO (Ribeirão Ouro). 
and hardness (Hard) (Golterman et al., 1978), biochemical oxygen demand (BOD) and total and fecal coliforms (APHA, 1998), total phosphorus (P) (Strickland and Parsons, 1960), total nitrogen (N) (Valderrama, 1981) and chlorophyll-a (Chl) (Nusch, 1980). Analyses of sodium (Na), potassium $(\mathrm{K})$, iron $(\mathrm{Fe})$, calcium $(\mathrm{Ca})$, magnesium $(\mathrm{Mg})$, zinc $(\mathrm{Zn})$ and manganese $(\mathrm{Mn})$ were measured by atomic absorption spectrophotometry using a spectrophotometer Model "A Analyst 100", brand Perkin Elmer.

Environmental level of integrity at collection points was determined by applying the Rapid Assessment Protocol (RAP) developed by Callisto et al. (2002). Eutrophication rate of MMM HPS tributaries was estimated by calculating the Trophic Level Index (TLI) of Lamparelli (2004).

\subsection{Sampling of benthic macroinvertebrates}

Three sediment samples were collected at each point for analysis of benthonic macroinvertebrate community using a granulometric sieve $(500 \mu \mathrm{M})$, when affluents presented low depth (i.e. $\leq 50 \mathrm{~cm}$-all springs). For environments with greater depths (i.e. $>100 \mathrm{~cm}$ - all river mouths) a modified Petersentype sampler was used (area: $353 \mathrm{~cm}^{2}$ ). Collected samples were taken to the laboratory and washed in a sieve with $210 \mu \mathrm{m}$ mesh. Samples were then placed in lighted trays for screening and detected organisms were preserved in $70 \%$ ethanol for later identification with a stereoscopic microscope. Benthic macroinvertebrates were identified to the taxonomic level of family (except Class Oligochaeta) based on keys and identification guides such as Róldan-Pérez (1988), Merritt and Cummins (1996) and Costa et al. (2006).

\subsection{Data analysis}

A cluster analysis using data of physical, chemical and biological characteristics of the MMM HPS tributaries was applied to segregate locations that were better preserved, that had greater human interference and tributaries that presented greater similarities. This data was obtained using the Ward's method based on Euclidean distance of dissimilarity, where the data base of these variables was previously centralized and normalized. Square root transformation of variable values was necessary since the unit presented different scales.

Principal Component Analysis (PCA) was applied to sort and summarize physical, chemical and biological variables recorded for the springs and mouths of the each fifth-order tributary inserted in the MMM HPS reservoir

The Mann-Whitney test (U) was used to establish a possible difference in total abundance $(\mathrm{N})$ of benthic macroinvertebrates inhabiting the springs and river mouths. Comparisons between richness of benthic macroinvertebrates recorded for the springs and mouths of tributaries of the MMM HPS reservoir were established using Hotelling's $\mathrm{T}^{2}$ test.

All statistical analyses were performed using Statistica 8.0 software (StatSoft, 2007).

\section{Results}

Averages and standard deviations (sd) of data on each physical, chemical and biological parameter evaluated in the water samples taken from springs and mouths of 14 studied tributaries are shown in Tables 1 and 2, respectively. In general, all tributaries recorded low values of hardness, indicating minimum values of $\mathrm{Ca}^{+2}$ and $\mathrm{Mg}^{+2}$, characterizing them as soft water. The RSJ source presented the highest values for parameters of conductivity, organic matter, iron potassium and sodium, in comparison with other springs (Table 1).

In relation to concentration of dissolved oxygen, the springs were well oxygenated with values ranging from 8.14 and $13.86 \mathrm{mg} \cdot \mathrm{L}^{-1}$. However, a slight decline in oxygen concentration was detected in the direction of river mouths. A reverse trend was recorded in the concentration of organic matter for most tributaries, as observed in RES. This tributary showed a higher concentration of oxygen and a lower quantity of organic matter for its spring (10.52 and $2.71 \mathrm{mg} . \mathrm{L}^{-1}$, respectively) in relation to its mouth (8.13 and $5.31 \mathrm{mg} . \mathrm{L}^{-1}$, respectively). Of all the mouths, RB presented the lowest levels of dissolved oxygen and the highest levels of alkalinity, hardness, conductivity, organic matter, nitrogen, phosphorus, chlorophyll- $a$, calcium, magnesium, iron, potassium, sodium and total coliforms. However, the RF $[\mathrm{M}]$ had the highest phosphorus concentration (Table 2).

Low concentrations of zinc $\left(\sim 0.002 \mathrm{mg} . \mathrm{L}^{-1}\right)$ were only recorded for the RSJ spring and mouths of RES, RF and RSJ. Other tributaries did not show traces of this metal. Manganese was detected in higher concentrations at the mouth of RSP $\left(0.005 \mathrm{mg} . \mathrm{L}^{-1}\right)$ and lower concentrations $\left(>0.002 \mathrm{mg} . \mathrm{L}^{-1}\right)$ at the springs of RSJ, RE, RES, $\mathrm{RF}, \mathrm{RC}$ and $\mathrm{RO}$ and the mouths of CO, RES, RSJ, $\mathrm{RF}$ and RG. 
Table 1. Averages values $( \pm s \mathrm{~d})$ of limnological variables $(\mathrm{N}: 18)$ from springs of the tributaries inserted in Mascarenhas de Morais HPS (Minas Gerais, Brazil) during the Sep. 2009 and Jun. 2011. For abbreviations see Figure 1. Zn and $\mathrm{Mn}$ are not represented due the low values.

\begin{tabular}{|c|c|c|c|c|c|c|c|c|c|c|c|c|c|c|}
\hline & & & & & $\mathbf{G}$ & & $\mathbf{F}$ & & כ & & J & & 0 & 0 \\
\hline & & & & & & & & & & & & & & \\
\hline & & & & & & & & & & & & & & \\
\hline & & & & & & & & & & & & & & \\
\hline & & ) & & & & & & & & & & & & \\
\hline & ( & & & & & & & & & & & & & \\
\hline & & 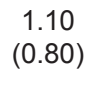 & $(0.8$ & & & & & & & & & & & \\
\hline & 1 & ) & 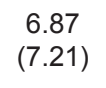 & & & & & & & & & & & \\
\hline & & ) & & & & & & & & & & & & \\
\hline & & ) & & & & & & & & & & & & \\
\hline & & ) & & & & & & & & & & & & \\
\hline & & ) & & & & & & & & & & & & \\
\hline & & $\begin{array}{c}2.07 \\
(0.32)\end{array}$ & & & & & & & & & & & & \\
\hline & & $\begin{array}{c}0 . C \\
(0 . C\end{array}$ & & & & & & & & & & & & \\
\hline & 4) & $\begin{array}{c}0.94 \\
(0.20)\end{array}$ & $\begin{array}{c}2.14 \\
(1.07)\end{array}$ & & & & & & & & & & & \\
\hline & 1 & (U) & (0. & (0. & (0) & & & & & & & & & \\
\hline ת & $\begin{array}{c}198 \\
(183)\end{array}$ & $\begin{array}{c}201 \\
(346)\end{array}$ & $\begin{array}{c}31 \\
(26)\end{array}$ & & & & & & & & & & & 4) \\
\hline
\end{tabular}

Values obtained using the Rapid Assessment Protocol (Callisto et al., 2002) (Table 3) show that springs of RC, RE, RB, RBJ, RSA and RES presented the lowest levels of environmental alterations and impact and the best state of conservation when compared with other study sites. RCO [S,M]; RO[S,M]; RSJ [S,M]; RF [M] and $\mathrm{CO}[\mathrm{M}]$ presented the lowest values based on RAP, which classifies them as highly impacted environments that are consequently considered highly degraded and exposed to human influence.

Cluster analysis of physical, chemical and biological variables in the water of these tributaries revealed the existence of two groups (Figure 2). Group I comprises tributaries with the greatest anthropogenic influence, which were then divided into two subgroups, where Ia showed higher environmental quality in relation to Ib. However, both groups recorded TLI values between 54 and 63, characterizing them as eutrophic tributaries. Group II mainly comprises tributaries with difficult access and low impact levels, subsequently resulting in higher RAP and DO levels and lower loads for $\mathrm{MO}$ and total coliforms. Group II tributaries were classified as mesotrophic by TLI, with values between 48 and 53 .

Figure 3 shows PCA sorting for limnological variables and tributaries inserted in the MMM HPS reservoir. Analysis revealed that the first two axes explained $52.4 \%$ of data variability. Axis 1 accounted for $36.0 \%$, being highly negatively correlated with conductivity (sc: -0.95 ), alkalinity (sc: -0.94$)$, hardness (sc: -0.87 ) and potassium (sc: -0.83 ), variables with the highest values in the 
Table 2. Averages values ( \pm sd) of limnological variables ( $N$ : 18) from river mouths of the tributaries inserted in Mascarenhas de Morais HPS (Minas Gerais, Brazil) during the Sep. 2009 and Jun. 2011. For abbreviations see Figure $1 . \mathrm{Zn}$ and $\mathrm{Mn}$ are not represented due the low values.

\begin{tabular}{|c|c|c|c|c|c|c|c|c|c|c|c|c|c|c|}
\hline Variables & $\mathrm{RC}$ & RE & RBJ & RSA & RG & RES & RF & RCA & RCO & RB & RSJ & RSP & $\mathrm{CO}$ & RO \\
\hline $\begin{array}{l}\mathrm{Alk} \\
\left.\mathrm{mg} \cdot \mathrm{L}^{-1}\right)\end{array}$ & $\begin{array}{l}27.05 \\
(7.88)\end{array}$ & $\begin{array}{l}11.09 \\
(2.65)\end{array}$ & & $\begin{array}{c}9.41 \\
(2.67)\end{array}$ & & $\begin{array}{c}24.50 \\
(15.31)\end{array}$ & $\begin{array}{l}11.42 \\
(2.69)\end{array}$ & $\begin{array}{l}21.83 \\
(8.71)\end{array}$ & $\begin{array}{c}33.25 \\
(10.27)\end{array}$ & & $\begin{array}{l}26.96 \\
(7.68)\end{array}$ & $\begin{array}{l}18.58 \\
(4.17)\end{array}$ & $\begin{array}{l}14.96 \\
(5.53)\end{array}$ & $\begin{array}{l}13.12 \\
(6.96)\end{array}$ \\
\hline $\begin{array}{l}\text { ard } \\
\left.g . L^{-1}\right)\end{array}$ & $\begin{array}{c}26.90 \\
(10.45)\end{array}$ & $\begin{array}{c}13 \\
(4.14)\end{array}$ & (12.85) & $\begin{array}{l}12.47 \\
(4.89)\end{array}$ & & $\begin{array}{c}23.16 \\
(17.48)\end{array}$ & $\begin{array}{l}17.78 \\
(6.76)\end{array}$ & $\begin{array}{l}16.65 \\
(6.63)\end{array}$ & $\begin{array}{c}37.02 \\
(11.85)\end{array}$ & $\begin{array}{l}46.78 \\
(9.92)\end{array}$ & $\begin{array}{l}25.27 \\
(6.01)\end{array}$ & $\begin{array}{l}26.33 \\
(7.17)\end{array}$ & $\begin{array}{l}19.71 \\
(9.01)\end{array}$ & $\begin{array}{l}14.30 \\
(8.44)\end{array}$ \\
\hline $\mathrm{pH}$ & $\begin{array}{c}7.31 \\
(0.22)\end{array}$ & $\begin{array}{c}7.08 \\
(0.36)\end{array}$ & $\begin{array}{c}7.08 \\
(0.25)\end{array}$ & $\begin{array}{c}6.73 \\
(0.22)\end{array}$ & 9) & $\begin{array}{c}6.87 \\
(0.58)\end{array}$ & $\begin{array}{c}6.75 \\
(0.44)\end{array}$ & $\begin{array}{c}6.96 \\
(0.22)\end{array}$ & $\begin{array}{c}7.38 \\
(0.26)\end{array}$ & $\begin{array}{c}6.96 \\
(0.19)\end{array}$ & $\begin{array}{l}7.04 \\
(0.28)\end{array}$ & $\begin{array}{l}7.03 \\
(0.33)\end{array}$ & $\begin{array}{c}6.85 \\
(0.63)\end{array}$ & $\begin{array}{c}7.19 \\
(0.18)\end{array}$ \\
\hline.$\left.L^{-1}\right)$ & $\begin{array}{c}9.70 \\
(2.14)\end{array}$ & $\begin{array}{l}10.88 \\
(4.96)\end{array}$ & $\begin{array}{l}10.71 \\
(3.41)\end{array}$ & $\begin{array}{l}10.05 \\
(2.34)\end{array}$ & $\begin{array}{l}10.20 \\
(2.66)\end{array}$ & $\begin{array}{c}8.13 \\
(2.02)\end{array}$ & $\begin{array}{l}10.48 \\
(4.83)\end{array}$ & $\begin{array}{c}9.08 \\
(1.61)\end{array}$ & $\begin{array}{c}7.60 \\
(1.65)\end{array}$ & $\begin{array}{l}6.34 \\
(2.87)\end{array}$ & $\begin{array}{l}10.83 \\
(3.12)\end{array}$ & $\begin{array}{l}8.77 \\
(2.41)\end{array}$ & $\begin{array}{c}9.43 \\
(1.42)\end{array}$ & $\begin{array}{l}9.85 \\
(2.76)\end{array}$ \\
\hline $\begin{array}{l}\text { Cond } \\
\left(\mathrm{mS} . \mathrm{m}^{-1}\right)\end{array}$ & $\begin{array}{c}57.77 \\
(13.40)\end{array}$ & $\begin{array}{l}25.36 \\
(9.16)\end{array}$ & $\begin{array}{l}39.7 \\
(20.1\end{array}$ & $\begin{array}{l}21.19 \\
(5.05)\end{array}$ & & & $\begin{array}{c}33.61 \\
(18.91)\end{array}$ & & $\begin{array}{l}75.41 \\
(9.21)\end{array}$ & & & $\begin{array}{l}46 . \\
(11 .\end{array}$ & $\begin{array}{c}39.98 \\
(13.96)\end{array}$ & $\begin{array}{l}25.09 \\
(6.21)\end{array}$ \\
\hline $\begin{array}{l}\mathrm{OM} \\
\left(\mathrm{mg} \cdot \mathrm{L}^{-1}\right)\end{array}$ & $\begin{array}{c}1.06 \\
(0.45)\end{array}$ & $\begin{array}{c}1.32 \\
(0.89)\end{array}$ & $\begin{array}{c}2.60 \\
(1.87)\end{array}$ & $\begin{array}{c}2.01 \\
(1.35)\end{array}$ & & $\begin{array}{c}5.31 \\
(2.02)\end{array}$ & $\begin{array}{c}3.79 \\
(3.29)\end{array}$ & $\begin{array}{c}2.96 \\
(3.01)\end{array}$ & $\begin{array}{c}2.28 \\
(1.28)\end{array}$ & $\begin{array}{l}4.27 \\
(2.01)\end{array}$ & $\begin{array}{l}2.38 \\
(1.25)\end{array}$ & $\begin{array}{l}2.30 \\
(1.14)\end{array}$ & $\begin{array}{c}2.85 \\
(1.46)\end{array}$ & $\begin{array}{l}1.35 \\
(1.03)\end{array}$ \\
\hline $\begin{array}{l}\text { BOD } \\
\left(\mathrm{mg} \cdot \mathrm{L}^{-1}\right.\end{array}$ & $\begin{array}{c}2.72 \\
(1.33)\end{array}$ & $\begin{array}{c}4.92 \\
(5.73)\end{array}$ & $\begin{array}{c}1.77 \\
(2.22)\end{array}$ & $\begin{array}{c}2.72 \\
(2.34)\end{array}$ & & $\begin{array}{c}2.43 \\
(0.38)\end{array}$ & $\begin{array}{c}5.77 \\
(4.20)\end{array}$ & $\begin{array}{c}5.73 \\
(5.46)\end{array}$ & $\begin{array}{c}11.45 \\
(11.11)\end{array}$ & $\begin{array}{c}7.68 \\
\text { (7.08) }\end{array}$ & $\begin{array}{c}4.82 \\
(3.06)\end{array}$ & $\begin{array}{l}7.83 \\
(6.85)\end{array}$ & $\begin{array}{c}4.62 \\
(5.58)\end{array}$ & $\begin{array}{l}4.67 \\
(4.90)\end{array}$ \\
\hline $\mathrm{N}$ & $\begin{array}{c}2.10 \\
(2.95)\end{array}$ & $\begin{array}{c}1.06 \\
(0.86)\end{array}$ & $\begin{array}{c}1.75 \\
(0.79)\end{array}$ & & & $\begin{array}{c}0.77 \\
(0.44)\end{array}$ & $\begin{array}{c}1.29 \\
(0.81)\end{array}$ & $\begin{array}{c}0.17 \\
(0.14)\end{array}$ & $\begin{array}{c}2.00 \\
(1.00)\end{array}$ & & $\begin{array}{c}0.65 \\
(0.48)\end{array}$ & $\begin{array}{c}0.78 \\
(0.68)\end{array}$ & $\begin{array}{c}1.59 \\
(0.68)\end{array}$ & \\
\hline$P$ & $\begin{array}{c}0.06 \\
(0.05)\end{array}$ & $\begin{array}{c}0.07 \\
(0.08)\end{array}$ & & & & $\begin{array}{c}0.04 \\
(0.06)\end{array}$ & $\begin{array}{c}0.35 \\
(0.79)\end{array}$ & $\begin{array}{c}0.05 \\
(0.03)\end{array}$ & $\begin{array}{c}0.06 \\
(0.04)\end{array}$ & & & & $\begin{array}{c}0.03 \\
(0.04)\end{array}$ & \\
\hline $\begin{array}{l}\mathrm{Chl} \\
\left(\mu \mathrm{g} \cdot \mathrm{L}^{-1}\right)\end{array}$ & $\begin{array}{c}0.13 \\
(0.33)\end{array}$ & $\begin{array}{c}0.18 \\
(0.27\end{array}$ & $\begin{array}{c}0.28 \\
(0.34)\end{array}$ & & & $\begin{array}{l}35 \\
32)\end{array}$ & $\begin{array}{c}0.62 \\
(0.60)\end{array}$ & $\begin{array}{c}2.02 \\
(3.33)\end{array}$ & $\begin{array}{c}0 . \\
(0 .\end{array}$ & & & & $\begin{array}{c}0.36 \\
(0.62)\end{array}$ & $\begin{array}{c}0.25 \\
(0.41)\end{array}$ \\
\hline $\begin{array}{l}\mathrm{Ca} \\
\left(\mathrm{mg} \cdot \mathrm{L}^{-1}\right)\end{array}$ & $\begin{array}{c}8.72 \\
(2.62)\end{array}$ & $\begin{array}{c}5.08 \\
(2.88)\end{array}$ & $\begin{array}{c}5.98 \\
(1.60)\end{array}$ & $\begin{array}{c}3.02 \\
(1.29)\end{array}$ & & $\begin{array}{c}2.55 \\
(1.09)\end{array}$ & $\begin{array}{c}3.05 \\
(2.06)\end{array}$ & $\begin{array}{c}3.40 \\
(0.39)\end{array}$ & $\begin{array}{c}7.77 \\
(1.98)\end{array}$ & $\begin{array}{r}9 . \\
(1 .\end{array}$ & & $\begin{array}{c}5.62 \\
(2.21)\end{array}$ & $\begin{array}{c}3.90 \\
(1.22)\end{array}$ & \\
\hline $\begin{array}{l}\mathrm{Mg} \\
\left(\mathrm{mg} \cdot \mathrm{L}^{-1}\right)\end{array}$ & $\begin{array}{c}1.94 \\
(0.33)\end{array}$ & $\begin{array}{c}1.03 \\
(0.33)\end{array}$ & $\begin{array}{c}1.83 \\
(0.65)\end{array}$ & & & $\begin{array}{c}1.03 \\
(0.48)\end{array}$ & $\begin{array}{c}0.83 \\
(0.23)\end{array}$ & $\begin{array}{c}1.60 \\
(0.42)\end{array}$ & $\begin{array}{c}1.96 \\
(0.83)\end{array}$ & $\begin{array}{c}2.51 \\
(0.21)\end{array}$ & $\begin{array}{c}2.02 \\
(0.60)\end{array}$ & $\begin{array}{c}1.83 \\
(0.52)\end{array}$ & $\begin{array}{c}1.69 \\
(0.26)\end{array}$ & $\begin{array}{c}1.04 \\
(0.18)\end{array}$ \\
\hline $\begin{array}{l}\mathrm{Fe} \\
\left(\mathrm{mg} \cdot \mathrm{L}^{-1}\right)\end{array}$ & $\begin{array}{c}0.21 \\
(0.14)\end{array}$ & $\begin{array}{c}0.16 \\
(0.13)\end{array}$ & $\begin{array}{c}0.57 \\
(0.73)\end{array}$ & $\begin{array}{c}0.35 \\
(0.41)\end{array}$ & $\begin{array}{c}0.39 \\
(0.45)\end{array}$ & $\begin{array}{c}1.18 \\
(1.18)\end{array}$ & $\begin{array}{c}1.20 \\
(1.00)\end{array}$ & $\begin{array}{c}1.26 \\
(0.77)\end{array}$ & $\begin{array}{c}0.57 \\
(0.47)\end{array}$ & $\begin{array}{c}0.87 \\
(0.63)\end{array}$ & $\begin{array}{c}1.34 \\
(1.24)\end{array}$ & $\begin{array}{c}1.37 \\
(2.54)\end{array}$ & $\begin{array}{c}1.05 \\
(0.91)\end{array}$ & $\begin{array}{c}0.98 \\
(0.67)\end{array}$ \\
\hline $\begin{array}{l}\mathrm{K} \\
\left(\mathrm{mg} \cdot \mathrm{L}^{-1}\right)\end{array}$ & $\begin{array}{c}1.16 \\
(0.27)\end{array}$ & $\begin{array}{c}0.44 \\
(0.24)\end{array}$ & $\begin{array}{c}1.19 \\
(0.46)\end{array}$ & $\begin{array}{c}0.49 \\
(0.22)\end{array}$ & & $\begin{array}{c}1.05 \\
(0.97)\end{array}$ & $\begin{array}{c}1.74 \\
(1.49)\end{array}$ & $\begin{array}{c}2.63 \\
(1.12)\end{array}$ & $\begin{array}{c}1.95 \\
(0.71)\end{array}$ & $\begin{array}{c}3.80 \\
(1.09)\end{array}$ & $\begin{array}{c}3.44 \\
(1.87)\end{array}$ & $\begin{array}{c}2.10 \\
(0.55)\end{array}$ & $\begin{array}{c}1.85 \\
(0.74)\end{array}$ & $\begin{array}{c}0.84 \\
(0.16)\end{array}$ \\
\hline $\begin{array}{l}\mathrm{Na} \\
\left(\mathrm{mg} \cdot \mathrm{L}^{-1}\right)\end{array}$ & $\begin{array}{c}1.47 \\
(0.23)\end{array}$ & $\begin{array}{c}0.82 \\
(0.14)\end{array}$ & $\begin{array}{c}1.23 \\
(0.46)\end{array}$ & $\begin{array}{c}0.49 \\
(0.25)\end{array}$ & $\begin{array}{c}0.17 \\
(0.24)\end{array}$ & $\begin{array}{c}2.04 \\
(1.35)\end{array}$ & $\begin{array}{c}2.39 \\
(2.14)\end{array}$ & $\begin{array}{c}3.66 \\
(0.79)\end{array}$ & $\begin{array}{c}3.90 \\
(1.03)\end{array}$ & $\begin{array}{c}7.63 \\
(2.06)\end{array}$ & $\begin{array}{c}4.95 \\
(1.70)\end{array}$ & $\begin{array}{c}1.98 \\
(0.62)\end{array}$ & $\begin{array}{c}2.24 \\
(0.54)\end{array}$ & $\begin{array}{c}1.04 \\
(0.46)\end{array}$ \\
\hline $\begin{array}{l}\text { Col } \\
\text { (NMP) }\end{array}$ & $\begin{array}{c}92 \\
(63)\end{array}$ & $\begin{array}{c}273 \\
(650)\end{array}$ & $\begin{array}{c}289 \\
(642)\end{array}$ & $\begin{array}{c}69 \\
(114)\end{array}$ & $\begin{array}{c}233 \\
(341)\end{array}$ & $\begin{array}{c}22 \\
(30)\end{array}$ & $\begin{array}{c}54 \\
(39)\end{array}$ & $\begin{array}{c}761 \\
(717)\end{array}$ & $\begin{array}{c}225 \\
(209)\end{array}$ & & $\begin{array}{c}220 \\
(253)\end{array}$ & $\begin{array}{c}8 \\
(9)\end{array}$ & $\begin{array}{c}52 \\
(59)\end{array}$ & $\begin{array}{c}131 \\
(200)\end{array}$ \\
\hline
\end{tabular}

subgroup Ib tributaries. In the positive direction, axis 1 correlated with DO (sc: 0.58$)$ and RAP (sc: 0.37 ), associated with tributaries of subgroup Ia and group II. Axis 2 accounted for $16.4 \%$, positively correlating with iron (sc: 0.73$)$ and organic matter (sc: 0.67 ) and negatively for RAP (sc: -0.55 ). Results show that axis 1 spatially segregated the groups and, in some cases, separated the most polluted and eutrophic tributaries (subgroup Ib) from the best preserved (group II) and moderately impacted (subgroup Ia).

A total of 8,987 individuals from 36 families of macroinvertebrates were identified in MMM HPS tributaries (Figure 4). The benthic community was composed of taxa belonging to the Phylum Arthropoda - Orders Coleoptera, Diptera, Ephemeroptera, Hemiptera, Odonata, Plecoptera, Trichoptera and Acari and - and Phylum
Table 3. Values of ecological conditions of tributaries inserted in Mascarenhas de Morais HPS (Minas Gerais, Brazil), using Rapid Assessment Protocol by Callisto et al. (2002).

\begin{tabular}{ccc}
\hline \multirow{2}{*}{ Sites } & \multicolumn{2}{c}{ Habitat diversity evaluation scores } \\
\cline { 2 - 3 } & Springs & Mouths \\
\hline RC & $79^{+++}$ & $43^{++}$ \\
RE & $83^{+++}$ & $26^{+}$ \\
RBJ & $72^{+++}$ & $41^{++}$ \\
RSA & $66^{+++}$ & $41^{++}$ \\
RG & $58^{++}$ & $42^{++}$ \\
RES & $86^{+++}$ & $37^{+}$ \\
RF & $54^{++}$ & $23^{+}$ \\
RCA & $42^{++}$ & $20^{+}$ \\
RCO & $28^{+}$ & $17^{+}$ \\
RB & $88^{+++}$ & $15^{+}$ \\
RSJ & $28^{+}$ & $22^{+}$ \\
RSP & $50^{++}$ & $21^{+}$ \\
CO & $55^{++}$ & $26^{+}$ \\
RO & $24^{+}$ & $22^{+}$ \\
\hline
\end{tabular}

+: Impacted areas; ++: altered areas; +++: natural areas. 


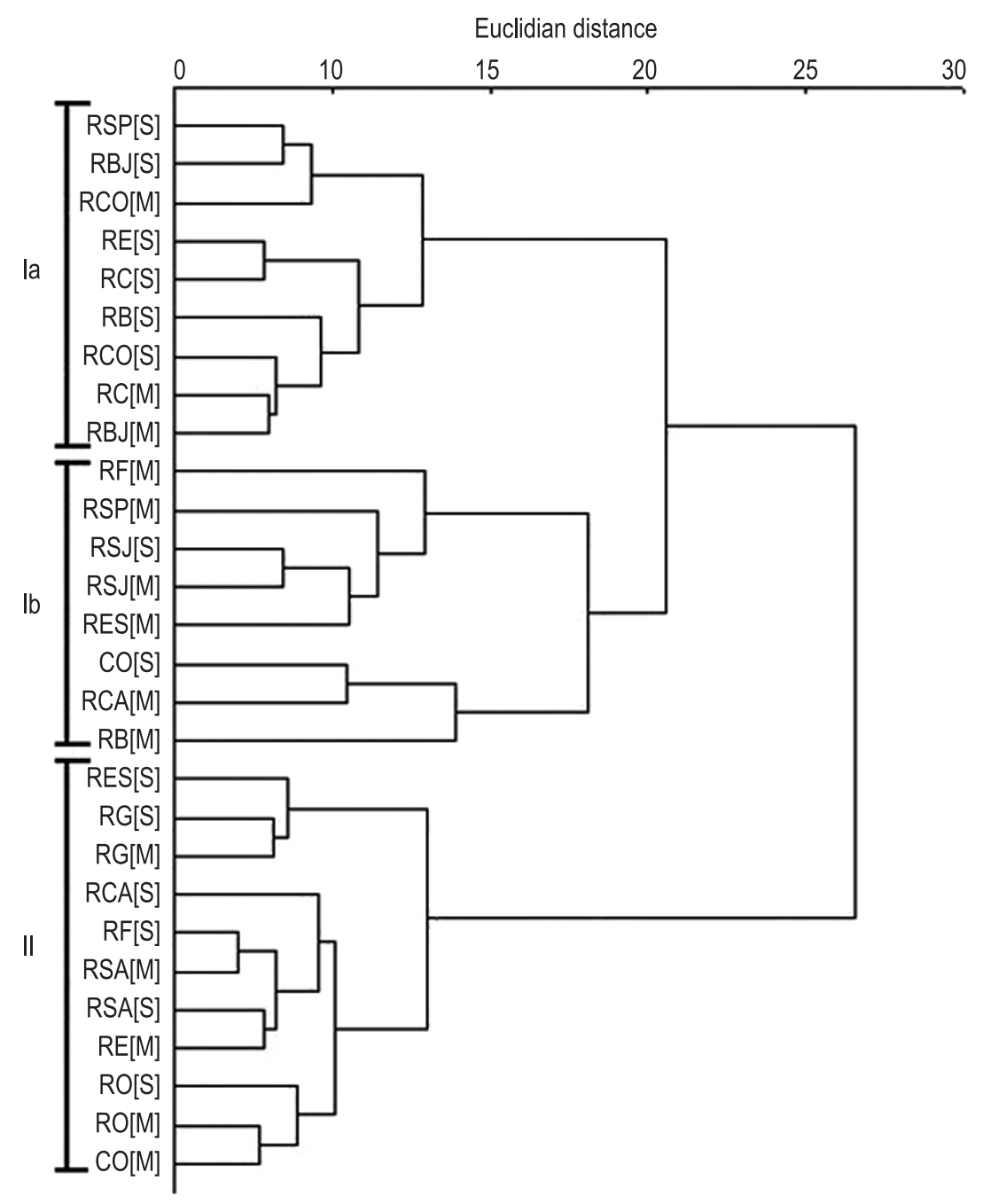

Figure 2. Dendrogram resulting from Cluster analysis based on similarities among the physical, chemical and biological variables of the tributaries inserted in Mascarenhas de Morais HPS (Minas Gerais, Brazil) in the period of September 2009 to June 2011. S: springs; M: river mouths.

Anellida - Classes Oligochaeta and Hirudinea. The Chironomidae (Diptera) family was the most abundant, accounting for $77 \%(\mathrm{~N}: 3,556$ [S] and 3,366 [M] individuals) of total macrofauna, followed by Oligochaeta (N: 334 [S] and 466 [M] individuals) and Baetidae (Ephemeroptera), which respectively contributed with 4 and $10 \%$.

There was no significant difference in total abundance of benthic macroinvertebrates inhabiting the springs $(\mathrm{N}: 4,300)$ and mouths $(\mathrm{N}: 4,687)$ (Mann Whitney $U=567, \mathrm{p}: 0.36$ ), and no significant difference between taxa richness of macroinvertebrates inhabiting springs and mouths (Hotelling's $\mathrm{T}^{2}, \mathrm{~F}=1.8$, p: 0.22 ). However, some taxa occurred exclusively for springs and others for mouths (Figure 4).

\section{Discussion}

According to CONAMA Resolution 357/2005 (Brasil, 2012a) that classifies water resources and establishes environmental guidelines, concentration of dissolved oxygen recorded in the tributaries - streams and mouths - exceeded $6 \mathrm{mg} . \mathrm{L}^{-1}$, classifying these waters as Class 1 , that is, ecologically balanced environments.

However, BOD concentration in the springs of RBJ, RSA, RF, RCA and RSP and the mouths of RF, RCA, RCO, RB and RSP were high ( $\left.>5 \mathrm{mg} \cdot \mathrm{L}^{-1}\right)$, classifying them as Class 3 tributaries according to CONAMA Resolution 357/2005 (Brasil, 2012a), indicating environmental changes in these areas. RCO [M] was the only tributary classified as Class 4 of the BOD parameter due to the high average value recorded for the tributary $\left(11.45 \mathrm{mg} . \mathrm{L}^{-1}\right)$. 


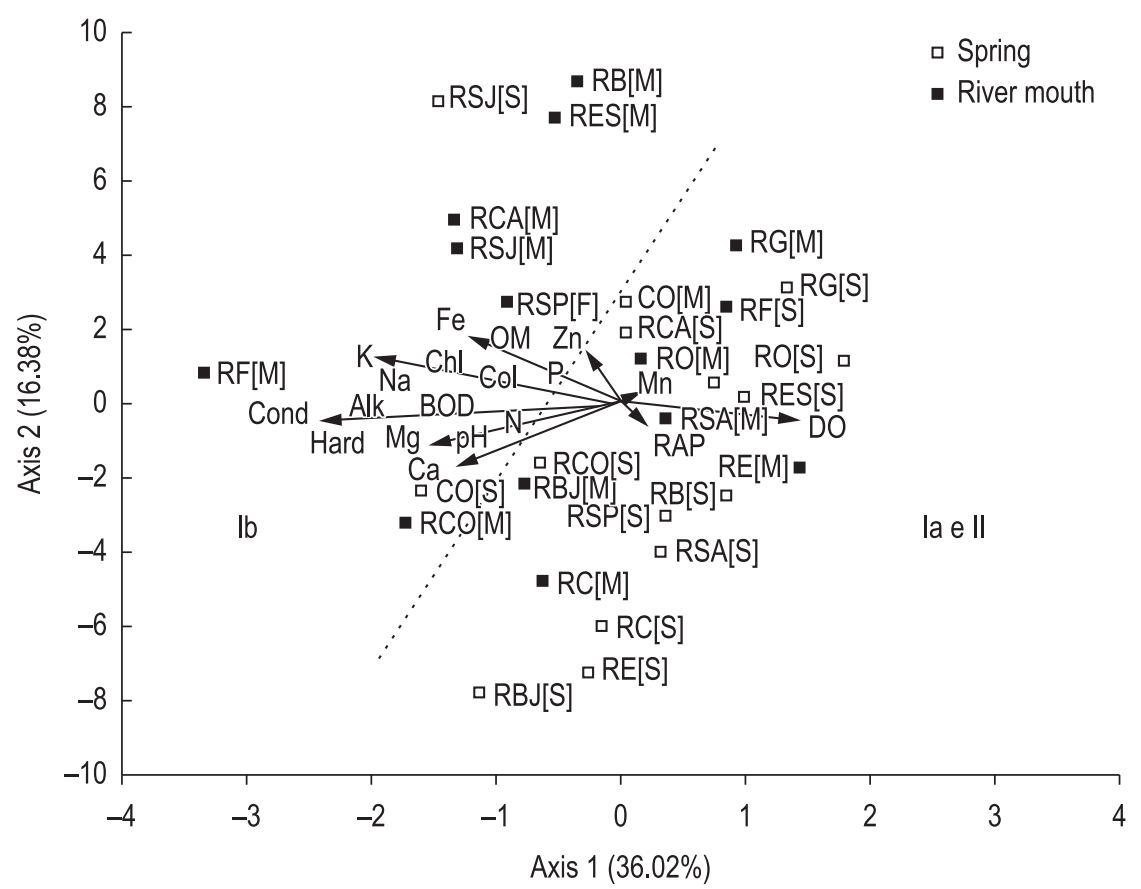

Figure 3. Ordination diagram by Principal components analysis (PCA) of scores and weights of physical, chemical and biological variables of water and Mascarenhas de Morais HPS tributaries (Minas Gerais, Brazil). Dotted line was drawn for illustrative purposes, indicating the (non)impacted tributaries.

These values are probably the result of excessive nitrogen and phosphorus nutrients available in the water, produced by domestic, industrial and agricultural waste released without prior treatment (Paschoal et al., 2012), recorded in larger quantities in the mouths and springs of $\mathrm{RC}, \mathrm{RE}, \mathrm{RBJ}$ and the mouths of RF, RCA, RCO and RB (Andrade, personal observation).

All tributaries have lotic characteristics with a high number of waterfalls and distances between margins of 10 to $15 \mathrm{~m}$, except in RSA $(31 \mathrm{~m})$ (Andrade, personal observation). von Sperling (2005) and Palma-Silva et al. (2007) claim that these environmental characteristics favour selfdepuration of organic compounds in water, which cause high concentrations of dissolved oxygen and subsequently increase the environmental quality of water bodies. In the case of tributaries studied in this study, favourable hydrogeological characteristics were not sufficient to minimize impacts caused by the discharging of organic and inorganic compounds into the stream, conferring eutrophic characteristics to most of these tributaries.

In general, cluster analysis effectively distinguished and grouped the tributaries in relation to environmental conservation and anthropogenic influences. While group II comprised springs and mouths with good water quality and non impacted environments, group I consisted of eutrophic tributaries that were altered and degraded by human activities. Group I was also divided into two subgroups, where Ia tributaries were characterized as having altered areas due to the impact of human activities, while Ib subgroup consisted of highly impacted tributaries (e.g. RSJ spring of and mouths RB and RF). RSJ [S] was characterized as having the most evident environmental changes in comparison with other springs due to its proximity to urban centres. Moreover, RB [M] and RF [M] have been receiving large amounts of organic and inorganic allochthonous contaminants along the more extensive portions of these rivers (Andrade, personal observation).

These observations corroborate the presuppositions of Tundisi (2003) and Tiburtius et al. (2004), who claim that population growth and the consequent pollution eventually degrade water bodies and significantly reduce their quality. These authors also stated that, of all the environmental problems caused by pollution, contamination of water bodies by untreated effluents may be the most important environmental problem. This claim was confirmed in this study as the high concentrations of phosphorus recorded for RB [M] and RF [M] were closely linked to the reduction of environmental quality in the study areas.

PCA analysis allows us to verify which physical, chemical and biological variables influenced water 


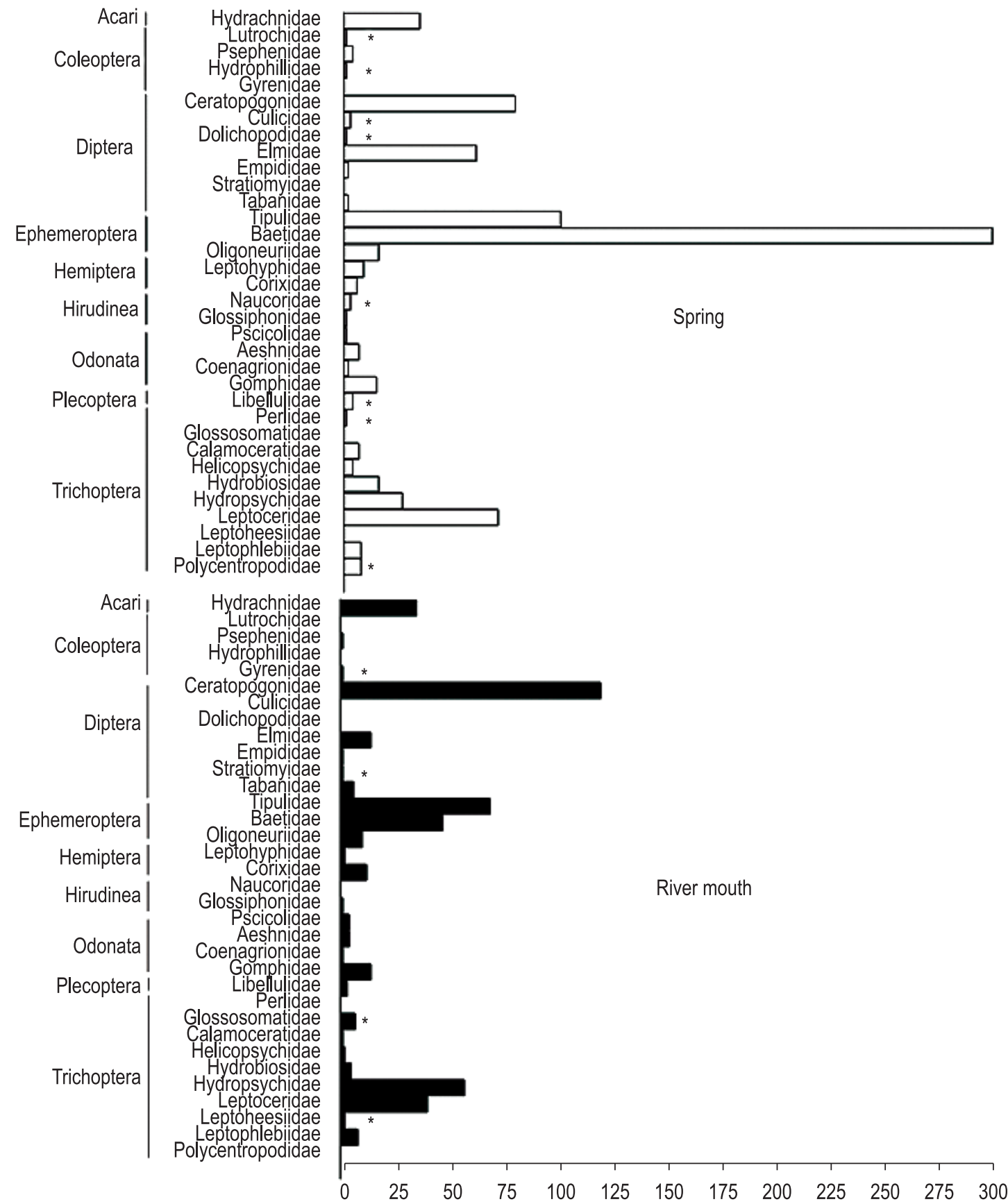

Figure 4. Abundance of macroinvertebrates (excluding Chironomidae and Oligochaeta) collected from the spring and river mouth from tributaries inserted in Mascarenhas de Morais HPS (Minas Gerais, Brazil) during the September 2009 and June 2011. *Indicates those taxa that occurred only in one area.

quality in the tributaries and which axis separated the impacted tributaries from the others (Figure 3). Furthermore, this analysis showed the differences in the patterns of impact caused by human activities in areas surrounding the reservoir.

Subgroup Ib and RCO [M] in the PCA corresponded to tributaries that presented high values of alkalinity, conductivity, hardness, potassium and organic matter. The areas of this subgroup are characterized by high population density and pollution caused by the discharging of untreated effluents. However, the PCA also shows that potassium was the variable that influenced distribution of tributaries, probably due to the use of NPK fertilizers in agricultural practices in these areas (Andrade, personal observation), resulting in high ionic concentrations in these sites and a deviation of other variables of this group.

Spatial segregation generated by the PCA axis 1 was based on high positive values recorded for 
RAP and DO in less or non-impacted tributaries. Thus, the Rapid Assessment Protocol developed by Callisto et al. (2002) proved to be a good indicator of environmental quality for small tributaries, as well as helping to segregate the bidimensional vector space, contributed significantly to the composition of axis 2 .

The benthic community of MMM HPS tributaries was mainly composed by the Order Diptera, which accounted for $78 \%$ of the sampled individuals, predominating in the springs and mouths. Callisto et al. (2001) suggests that representatives of this order are distributed among varied and quite extensive habitats. They also present a vast generic variety and can be found in rivers and lakes of different depths.

In this order, the Chironomidae family was the group with the highest abundance. Merritt and Cummins (1996) and Sanseverino et al. (1998) state that this is the most important group of aquatic insects, often occurring in high densities and diversity in most types of aquatic ecosystems. These authors relate their dominance in lotic environments to the fact that they can tolerate extreme environmental conditions (e.g. hypoxia and eutrophication), have high competitive capacity and the ability to colonize different environments.

In spite of the predominance of this family, the community of benthic macroinvertebrates collected in spring areas presented similar proportions to areas with mouths, with no significant differences between them. This result was associated to spatial homogeneity arising from anthropogenic influence in several tributaries analyzed in this study, as observed in RG, RCO, RSJ and RO (Table 3), thus reducing local diversity in these points.

Vannote et al. (1980) and Kawaguchi and Nakano (2001) state that in small tributaries, riparian and canopy vegetation surrounding these areas has a significant influence on composition and distribution of benthic fauna, which reduces autotrophic production by shading and promotes the entry of a large amount of allochthonous detritus. These authors also observed that reduction of light intensity limits abundance of organisms. According to Gregory et al. (1992) there is a bias that favours heterogeneity and diversity in benthic communities when they were exposed to areas with more light available for photosynthesis.

Although springs of the RCO, RF, RO and RSA and all mouths of the tributaries are exposed to luminosity, given the absence of surrounding vegetation, they did not present greater biological diversity and/or heterogeneity in comparison with non impacted (shaded) areas. In Brazil, areas with springs are considered permanent preservation areas (APP) according to CONAMA Resolution 303/2002 (Brasil, 2012b). Natural vegetation consists of riparian and canopy forest along its entire extension and any impact to this area is considered a crime. Nevertheless, an absence of this vegetation was observed in most mouths and in some springs of the tributaries, compromising the structure of benthic macrofauna and resulting in a homogeneous environment. Inoue and Nunokawa (2005) observe that the absence of riparian vegetation negatively affects benthic invertebrates and vertebrates because they alter the environmental scenery over time (e.g. geology and climate).

A useful observation was the presence/absence of certain exclusive taxa in areas of mouths and springs (Figure 4). In the springs, there was an exclusive occurrence of some families of Plecoptera, Trichoptera, Hirudinea, Diptera and a greater abundance of Ephemeroptera. Hodkinson and Jackson (2005) state that many species of Ephemeroptera, Plecoptera and Trichoptera usually occur in well-preserved environments. These authors also state that these species are sensitive to pollution and their presence indicates that water bodies are healthy. Róldan-Pérez (1988) points out that some macroinvertebrates are highly tolerant to pollution and indicate eutrophic environments, such as leeches (Hirudinea), flies (Diptera) and some beetles (Coleoptera). In spring areas, taxa commonly referred as indicators of eutrophic environments coexisted with taxa sensitive to environmental changes, so it is possible to confirm the homogeneity and environmental degradation of these areas.

Results show that most of the tributaries that supply and compose the MMM HPS reservoir and their surrounding areas have been degraded and present low water quality, confirming the initial assumption and complementing results obtained by Paschoal et al. (2012) that show higher mean values of trophic levels and lower water quality in areas with higher anthropogenic influence in lentic portions of MMM HPS. These results are probably related to the poor quality of water that reaches the reservoir through the tributaries. Evidently, the presence of humans has drastically affected water quality and faunal composition of tributaries due to inappropriate use, before they supply the MMM HPS. Consequently, a complementary study of the tributaries when working with issues related to reservoirs is considered necessary, given the direct 
influence of these components on water quality and composition of lentic environments. Immediate mitigating actions in these areas are required since this region has a significant social, historical and economic value.

\section{Acknowledgements}

The authors would like to thank Fundo de Recuperação, Proteção e Desenvolvimento Sustentável das Bacias Hidrográficas de Minas Gerais (FHIDRO), Fundação de Amparo a Pesquisa de Minas Gerais (FAPEMIG) and Fundação de Ensino Superior de Passos/Universidade do Estado de Minas Gerais (FESP/UEMG) for financing the project and helping in the logistical support in which the work can be performed successfully. We also thank all trainees for help in the field and in laboratory and Mrs. Cipriana Leme for her help with the English version of this paper.

\section{References}

Agência Nacional de Águas - ANA. 2012. Sistema Nacional de Informaçōes sobre recursos hidricos. Brasil: ANA. Available from: <http://portalsnirh.ana.gov. br>. Access in: 21 Aug. 2012.

American Public Health Association - APHA. 1998. Standard methods for the examination of water and wastewater. Washington: APHA. $1161 \mathrm{p}$.

BAIRD, C. 1995. Environmental chemistry. New York: WH Freeman Pub. 484 p.

Brasil. Ministério do Meio Ambiente. Conselho Nacional do Meio Ambiente - CONAMA. 2012a. Resolução $n^{\circ}$ 357, de 17 de março de 2005. Dispóe sobre a classificação dos corpos de água e diretrizes ambientais para o seu enquadramento, bem como estabelece as condiçōes e padröes de lançamento de efluentes, e dá outras providências. Brasília. 1126 p. (Resoluçóes do Conama: Resoluçóes vigentes publicadas entre setembro de 1984 e janeiro de 2012).

Brasil. Ministério do Meio Ambiente. Conselho Nacional do Meio Ambiente - CONAMA. 2012b. Resolução CONAMA no 303, de 20 de março de 2002. Dispóe sobre parâmetros, definiçôes e limites de Áreas de Preservação Permanente. Brasília. 1126 p. (Resoluçôes do Conama: Resoluçóes vigentes publicadas entre setembro de 1984 e janeiro de 2012).

CAllisto, M., FERreirA, W., MORENO, P., GOULART, MDC. and PETRUCIO, M. 2002. Aplicação de um protocolo de avaliação rápida da diversidade de habitats em atividades de ensino e pesquisa (MG-RJ). Acta Limnologica Brasiliensia, vol. 14, no. 1, p. 91-98.

CALLISTO, M., MORETTI, M. and GOULART, MDC. 2001. Macroinvertebrados bentônicos como ferramenta para avaliar a saúde de riachos. Revista Brasileira de Recursos Hídricos, vol. 6, p. 71-82.

COSTA, C., IDE, S. and SIMONKA, CE. 2006. Insetos Imaturos: Metamorfose e Identificação. Ribeirão Preto: Holos. 249 p.

GAUFIN, AR. and TARZWELL, CM. 1952. Aquatic invertebrates as indicators of stream pollution. Public Health Reports, vol. 67, p. 57-64. PMCid:2030707.

GOLTERMAN, HL., CLYMO, RS. and OHNSTAD, MAM. 1978. Methods for physical and chemical analysis of freshwaters. Oxford: Blackwell Scientific Publications. 213 p.

GREGORY, SV., SWANSON, FJ., McKEE, WA. and CUMMINS, KW. 1992. An ecosystem perspective of riparian zones. BioScience, vol. 41, p. 540-551.

HENRY, R. 1999. Ecologia de reservatórios: estrutura, função e aspectos sociais. Botucatu: Fapesp/ Fundibio. $800 \mathrm{p}$.

HODKINSON, ID. and JACKSON, JK. 2005. Terrestrial and Aquatic Invertebrates as Bioindicators for Environmental Monitoring, with Particular Reference to Mountain Ecosystems. Environmental Management, vol. 35, p. 649-666. http://dx.doi. org/10.1007/s00267-004-0211-x

INOUE, M. and NUNOKAWA, M. 2005. Spatial variation in density of stream benthic fishes in northern Hokkaido, Japan: does riparian vegetation affect fish density via food availability. Japanese Society of Limnology, vol. 6, p. 7-14. http://dx.doi. org/10.1007/s10201-004-0136-3

KAWAGUCHI, Y. and NAKANO, S. 2001. Contribution of terrestrial invertebrates to the annual resource budget for salmonids in forest and grassland reaches of a headwater stream. Freshwater Biology, vol. 46, p. 303-316. http://dx.doi.org/10.1046/j.13652427.2001.00667.x

LAMPARELLI, MC. 2004. Grau de trofia em corpos d'água do estado de São Paulo: avaliação dos métodos de monitoramento. São Paulo: Universidade de São Paulo. 238 p. [Tese de Doutorado em Ciência].

MERRITT, RW. and CUMMINS, KW. 1996. An Introduction to the Aquatic Insects of North America. Dubuque: Kendal, Hunt Publication Company. 862 p.

NUSCH, EA. 1980. Comparison of different methods for chlorophyll and phaeopigments determination. Archiv für Hydrobiologie-Beiheft Ergebnisse der Limnologie, vol. 14, p. 14-36.

PALMA-SILVA, GM., TAUK-TORNISIELO, SM. and PIÁO, AC. 2007. Capacidade de autodepuração de um trecho do rio Corumbataí, SP, Brasil. Holos Environment, vol. 7, no. 2, p. 139.

PASCHOAL, LRP., RIGOLIN-SÁ., O. and FERREIRA, MNL. 2012. Análise da qualidade da água utilizando o índice do estado trófico (IET) e o índice da qualidade da água (IQA). In RIGOLIN-SÁ, O., 
org. Bacia hidrográfica: Estudos do Rio Grande no Sudoeste de Minas Gerais- Brasil. Passos: Edifesp. p. 90-112.

ROMANO, AW., CASTRO, FDC. and MAGALHÁES, PCV. 1994. Mapa de ocorrências minerais não metálicas do estado de Minas Gerais (1: 1.000.000). Belo Horizonte: Companhia Mineradora de Minas Gerais.

RICCIARDI, A., PALMER, ME. and YAN, ND. 2011. Should biological invasions be managed as natural disasters? BioScience, vol. 61, p. 312-317. http:// dx.doi.org/10.1525/bio.2011.61.4.11

RÓLDAN-PÉREZ, G. 1988. Guia para el estudio de los macro invertebrados acuáticos del Departamento de Antioquia. Bogotá: Universidad de Antioquia. 216 p.

SANSEVERINO, AM., NESSIMIAN, JL. and OLIVEIRA, ALH. 1998. A fauna de Chironomidae (Diptera) em diferentes biótopos da Serra do Subaio (Teresópolis, RJ). In NESSIMIAN, JL. and CARVALHO, AL., eds. Ecologia de Insetos Aquáticos. Rio de Janeiro: Série Oecologia Brasiliensis. p. 253-263.

StatSoft. 2007. STATISTICA (data analysis software system). version 8.0. Available from: <http://www. statsoft.com>.

STRASKRABA, M. and TUNDISI, JG. 1999. Reservoir water quality management: Guidelines of Lake Management. Shiga: ILEC. 229 p.
STRICKLAND, JDH. and PARSONS, TR. 1960. A manual of seawater analysis. Bulletin of the Fisheries Research Board of Canada, vol. 125, p. 1-185.

TIBURTIUS, ERL., PERALTA-ZAMORA, P. and LEAL, ES. 2004. Contaminação de águas por BTXs e processos utilizados na remediaçáo de sítios contaminados. Quimica Nova, vol. 27, p. 441-446. http://dx.doi.org/10.1590/S010040422004000300014

TUNDISI, JG. 1993. Represas do Paraná superior: limnologia e bases científicas para o gerenciamento. In BOLTOVSKOY, A. and LÓPEZ, HL., eds. Conferencias de Limnologia. La Plata: Instituto de Limnologia "Dr. RA Ringuelet". p. 41-52.

TUNDISI, JG. 2003. Água no século XXI: enfrentando a escassez. São Carlos: Rima. 248 p.

United States of Environmental Protection Agency - USEPA. 2000. The History of Drinking Water Treatment. [Fact Sheet (EPA-816-F-00-006)]. Washington: Environmental Protection Agency - Office of Water.

VALDERRAMA, JC. 1981. The simultaneous analysis of total nitrogen and phosphorus in natural waters. Marine Chemistry, vol. 10, p. 109-122.

VANNOTE, RL., MINSHALL, GW., CUMMINS, KW., SEDEELL, JR. and CUSHING, CE. 1980. The river continuum concept. Canadian Journal of Fisheries and Aquatic Sciences, vol. 37, p. 130-137.

VON SPERLING, M. 2005. Introdução à qualidade das águas e ao tratamento de esgotos. Belo Horizonte: DESA-UFMG. $452 \mathrm{p}$. 